\title{
Correlation between thermodynamical stabilities of metal borohydrides and cation electronegativites: First-principles calculations and experiments
}

\author{
Yuko Nakamori, ${ }^{1}$ Kazutoshi Miwa, ${ }^{2, *}$ Akihito Ninomiya, ${ }^{1}$ Haiwen Li, ${ }^{1}$ Nobuko Ohba, ${ }^{2}$ Shin-ichi Towata, ${ }^{2}$ Andreas Züttel,,${ }^{3,4}$ \\ and Shin-ichi Orimo ${ }^{1, \dagger}$ \\ ${ }_{1}^{1}$ Institute for Materials Research, Tohoku University, Sendai 980-8577, Japan \\ ${ }^{2}$ Toyota Central Research and Development Laboratories, Inc., Nagakute, Aichi 480-1192, Japan \\ ${ }^{3}$ Physics Department, University of Fribourg, Perolles, Switzerland \\ ${ }^{4}$ EMPA, Department of Environment, Energy and Mobility, Dübendorf, Switzerland \\ (Received 16 February 2006; revised manuscript received 14 June 2006; published 28 July 2006)
}

\begin{abstract}
The thermodynamical stabilities for the series of metal borohydrides $M\left(\mathrm{BH}_{4}\right)_{n}(M=\mathrm{Li}, \mathrm{Na}, \mathrm{K}, \mathrm{Cu}, \mathrm{Mg}, \mathrm{Zn}$, $\mathrm{Sc}, \mathrm{Zr}$, and $\mathrm{Hf} ; n=1-4)$ have been systematically investigated by first-principles calculations. The results indicated that an ionic bonding between $M^{n+}$ cations and $\left[\mathrm{BH}_{4}\right]^{-}$anions exists in $M\left(\mathrm{BH}_{4}\right)_{n}$, and the charge transfer from $M^{n+}$ cations to $\left[\mathrm{BH}_{4}\right]^{-}$anions is a key feature for the stability of $M\left(\mathrm{BH}_{4}\right)_{n}$. A good correlation between the heat of formation $\Delta H_{\text {boro }}$ of $M\left(\mathrm{BH}_{4}\right)_{n}$ and the Pauling electronegativity of the cation $\chi_{P}$ can be found, which is represented by the linear relation, $\Delta H_{\text {boro }}=248.7 \chi_{P}-390.8$ in the unit of $\mathrm{kJ} / \mathrm{mol} \mathrm{BH}_{4}$. In order to confirm the predicted correlation experimentally, the hydrogen desorption reactions were studied for $M\left(\mathrm{BH}_{4}\right)_{n}(M=\mathrm{Li}, \mathrm{Na}, \mathrm{K}, \mathrm{Mg}, \mathrm{Zn}, \mathrm{Sc}, \mathrm{Zr}$, and $\mathrm{Hf})$, where the samples of the later five borohydrides were mechanochemically synthesized. The thermal desorption analyses indicate that $\mathrm{LiBH}_{4}, \mathrm{NaBH}_{4}$, and $\mathrm{KBH}_{4}$ desorb hydrogen to hydride phases. $\mathrm{Mg}\left(\mathrm{BH}_{4}\right)_{2}, \mathrm{Sc}\left(\mathrm{BH}_{4}\right)_{3}$, and $\mathrm{Zr}\left(\mathrm{BH}_{4}\right)_{4}$ show multistep desorption reactions through the intermediate phases of hydrides and/or borides. On the other hand, $\mathrm{Zn}\left(\mathrm{BH}_{4}\right)_{2}$ desorbs hydrogen and borane to elemental $\mathrm{Zn}$ due to instabilities of $\mathrm{Zn}$ hydride and boride. A correlation between the desorption temperature $T_{d}$ and the Pauling electronegativity $\chi_{P}$ is observed experimentally and so $\chi_{P}$ is an indicator to approximately estimate the stability of $M\left(\mathrm{BH}_{4}\right)_{n}$. The enthalpy change for the desorption reaction, $\Delta H_{\text {des }}$, is estimated using the predicted $\Delta H_{\text {boro }}$ and the reported data for decomposed product, $\Delta H_{\text {hyd/boride. The estimated }}$ $\Delta H_{\text {des }}$ show a good correlation with the observed $T_{d}$, indicating that the predicted stability of borohydride is experimentally supported. These results are useful for exploring $M\left(\mathrm{BH}_{4}\right)_{n}$ with appropriate stability as hydrogen storage materials.
\end{abstract}

DOI: 10.1103/PhysRevB.74.045126

\section{INTRODUCTION}

Complex hydrides have attracted considerable attention as hydrogen storage materials, because of their high gravimetric hydrogen densities. Since Bogdanović and Schwickardi have reported that the catalyzed sodium alanate $\left(\mathrm{NaAlH}_{4}\right)$ shows reversible hydrogen desorption and absorption reactions at moderate condition, ${ }^{1}$ many researches have been done for alkali complex hydrides mainly from the viewpoint of kinetics. ${ }^{2-10}$

Among alkali complex hydrides, lithium borohydride $\left(\mathrm{LiBH}_{4}\right)$ is one of the candidates for hydrogen storage materials because of its extremely high gravimetric hydrogen density (18 mass \%). $\mathrm{LiBH}_{4}$ mixed with $\mathrm{SiO}_{2}$ has been reported to desorb hydrogen below $673 \mathrm{~K}$ that is lower than pure $\mathrm{LiBH}_{4}$ does. ${ }^{11}$ In order to decrease the hydrogen desorption temperatures, especially to $300-400 \mathrm{~K}$, the systematic understanding of the thermodynamical stabilities is of great important. Recently, the stabilities of alkali borohydrides have been studied by first-principles calculation. ${ }^{12-16}$ Our calculated results for $\mathrm{LiBH}_{4}$ revealed that the charge compensation by $\mathrm{Li}^{+}$is a key feature for the stability of the internal bonding of $\left[\mathrm{BH}_{4}\right]^{-}$anion ${ }^{12}$ and it was expected that the suppression of the charge transfer by partial substitution of the element having larger electronegativity than $\mathrm{Li}$ is effective for lowering the hydrogen desorption temperature. ${ }^{17}$ In fact, $\mathrm{Mg}$-substituted $\mathrm{LiBH}_{4}$ has a lower thermal desorption temperature than pure $\mathrm{LiBH}_{4} \cdot{ }^{18}$
PACS number(s): 65.40.-b, 71.20.Ps, 61.66.Fn, 63.20.Dj

In this study, the stabilities of not only alkali borohydrides but also other metal borohydrides are investigated to systematic understand of the thermodynamical stabilities of borohydrides. The heats of formation of borohydrides $M\left(\mathrm{BH}_{4}\right)_{n}$, $(M=\mathrm{Li}, \mathrm{Na}, \mathrm{K}, \mathrm{Cu}, \mathrm{Mg}, \mathrm{Zn}, \mathrm{Sc}, \mathrm{Zr}$, and Hf, $n=1-4$; depending on valency) are predicted by first-principles calculations. And then, the thermal desorption temperatures are studied for $M\left(\mathrm{BH}_{4}\right)_{n}(M=\mathrm{Li}, \mathrm{Na}, \mathrm{K}, \mathrm{Mg}, \mathrm{Zn}, \mathrm{Sc}, \mathrm{Zr}$, and $\mathrm{Hf})$, where the samples of the later five borohydrides are mechanochemically synthesized.

In the theoretical prediction, the stabilities of metal borohydrides are discussed for the solid phase at the absolute zero temperature though some compounds show phase transitions below the hydrogen desorption temperature. Since the contribution of the latent heat for the phase transition to the energetics of the hydrogen desorption reaction is expected to be relatively modest, ${ }^{19}$ the predicted stabilities can be linked well to the experimental observations.

\section{METHODS}

\section{A. Computational method}

The present calculations were performed using the ultrasoft pseudopotential method ${ }^{20}$ based on density functional theory. ${ }^{21}$ The generalized gradient approximation ${ }^{22}$ is adopted for the exchange-correlation energy. The cutoff energies used in this study are 15 and 120 hartrees for the 
pseudowave functions and the charge density, respectively. The $k$-point grids for the Brillouin zone integration are generated so as to make the edge lengths of the grid elements as close to the target value of $0.08 \mathrm{bohr}^{-1}$ as possible. These computational conditions give good convergence for the total energy within $1 \mathrm{meV} /$ atom. The computational details can be found in Ref. 12 and the references therein.

\section{B. Experimental procedure}

$\mathrm{LiBH}_{4}, \mathrm{NaBH}_{4}$, and $\mathrm{KBH}_{4}$ with 95-99.9\% purities were purchased from Aldrich Co. LTD. $M\left(\mathrm{BH}_{4}\right)_{n}(M=\mathrm{Mg}, \mathrm{Zn}, \mathrm{Sc}$, $\mathrm{Zr}$, and $\mathrm{Hf}$ ) were synthesized by mechanical milling of the mixture of $\mathrm{MCl}_{n}$ and $n \mathrm{LiBH}_{4}$ under $0.1 \mathrm{MPa}$ argon atmosphere for 5 hours. Mechanochemical synthesis have been reported for preparation of $\mathrm{Zn}\left(\mathrm{BH}_{4}\right)_{2}$ (Ref. 23) and $\mathrm{Zr}\left(\mathrm{BH}_{4}\right)_{4} \cdot{ }^{24}$ The expected reaction during milling is expressed as follows:

$$
M \mathrm{Cl}_{n}+n \mathrm{LiBH}_{4} \rightarrow M\left(\mathrm{BH}_{4}\right)_{n}+n \mathrm{LiCl}
$$

The samples thus prepared were examined by powder x-ray diffraction measurement (PANalytical X'PERT with $\mathrm{Cu}-K \alpha$ radiation), Raman spectroscopy (Nicolet, Almega-HD, $532 \mathrm{~nm}$ laser with back scattering geometry) and thermal desorption spectroscopy detected by gas chromatography (GL Science GC323, argon flow rate of $40 \mathrm{ml} / \mathrm{min}$ and heating rate of $5 \mathrm{~K} / \mathrm{min}$ ). The samples were always handled in an argon glove box filled with purified argon (dew point below $183 \mathrm{~K}$ ) without exposing air. The experimental details were described in Refs. 25 and 26.

\section{RESULTS AND DISCUSSION}

\section{A. Theoretical predictions}

We have predicted the heats of formation $\Delta H_{\text {boro }}$ for several borohydrides. Although most metal cations considered here form hydrides and/or borides, we restrict ourselves in this section to the heats of formation corresponding to the following reaction:

$$
\frac{1}{n} M+\mathrm{B}+2 \mathrm{H}_{2} \rightarrow \frac{1}{n} M\left(\mathrm{BH}_{4}\right)_{n} .
$$

In order to compare the stability of borohydrides composed of the metal cations $M$ which have different valency, we normalize $\Delta H_{\text {boro }}$ by the number of $\mathrm{BH}_{4}$ complexes in the formula unit. The heat of formation is estimated from the difference of the total energies between the left- and righthand sides of Eq. (2). The zero-point energies (ZPEs) are not taken into account, unless otherwise noted. The metal cation in the borohydride contributes mainly to the librational vibrations whose frequencies are thought to be considerably lower than those of the internal B-H bending and stretching modes of $\left[\mathrm{BH}_{4}\right]^{-}$anions. ${ }^{12,17}$ The phonon frequencies of the bulk metal are also expected to be low. Therefore, the ZPE contributions to $\Delta H_{\text {boro }}$ become nearly constant for the reaction shown in Eq. (2), regardless of metal cations. From the vibrational frequencies obtained for an isolated $\left[\mathrm{BH}_{4}\right]^{-}$anion and an $\mathrm{H}_{2}$ molecule, ${ }^{12}$ the amount of the $\mathrm{ZPE}$ correction is estimated to be $33 \mathrm{~kJ} / \mathrm{mol} \mathrm{BH}_{4}$. This estimation agrees well with the ZPE correction of $34 \mathrm{~kJ} / \mathrm{mol} \mathrm{BH}_{4}$ for $\mathrm{LiBH}_{4}{ }^{12} \mathrm{We}$ also confirm that this approximation is $\operatorname{good}$ for $\mathrm{NaBH}_{4}$ as shown in the Appendix.

The predicted heats of formation without the ZPE correction for $\mathrm{LiBH}_{4}$ and $\mathrm{CuBH}_{4}$ are -194 and $43 \mathrm{~kJ} / \mathrm{mol} \mathrm{BH}_{4}$, respectively, which have been already presented in Refs. 12 and 17. The crystal structures of $\mathrm{NaBH}_{4}$ and $\mathrm{KBH}_{4}$ at ambient conditions are the $\mathrm{NaCl}$ type. ${ }^{27}$ For $\mathrm{NaBH}_{4}$, we obtain the lattice constant as $a=6.137 \AA$ which agrees well with the experimental values ${ }^{28}$ of $6.12 \AA$ and the heat of formation as $\Delta H_{\text {boro }}=-182 \mathrm{~kJ} / \mathrm{mol} \mathrm{BH}_{4}$. However, the phonon calculation gives a soft mode of $77 i \mathrm{~cm}^{-1}$ at the $\Gamma$ point, indicating that the cubic $\mathrm{NaCl}$-type structure is unstable at the zero temperature. This is most likely related to the phase transition to a tetragonal structure at low temperature. The recent structural analysis by neutron diffraction ${ }^{29}$ shows that the tetragonal phase has $P 4_{2} / n m c$ symmetry. We repeat the calculation for this phase and find the energy gain, $\Delta H_{\text {boro }}=-188 \mathrm{~kJ} / \mathrm{mol}$ $\mathrm{BH}_{4}$. For $\mathrm{NaCl}$-type $\mathrm{KBH}_{4}$, the lattice constant and the heat of formation are predicted to be $a=6.739 \AA$ and $\Delta H_{\text {boro }}=$ $-228 \mathrm{~kJ} / \mathrm{mol} \mathrm{BH}_{4}$, respectively. The agreement between the

TABLE I. Structural parameters of $\mathrm{NaBH}_{4}$ and $\mathrm{KBH}_{4}$. The values in parentheses are the experimental data (Ref. 29 for $\mathrm{NaBH}_{4}$ and $\mathrm{Ref}$.

\begin{tabular}{|c|c|c|c|c|c|c|c|}
\hline \multirow[b]{2}{*}{ Compound } & \multirow[b]{2}{*}{ Space group } & \multirow{2}{*}{$\begin{array}{l}\text { Lattice } \\
\text { parameters }(\AA)\end{array}$} & \multicolumn{5}{|c|}{ Atom parameters } \\
\hline & & & & Position & $x$ & $y$ & $z$ \\
\hline \multirow[t]{4}{*}{$\mathrm{NaBH}_{4}$} & \multirow[t]{4}{*}{$P 4_{2} / n m c$ (No.137) } & $a=4.339$ & $\mathrm{Na}$ & $2 a$ & 0 & 0 & 0 \\
\hline & & $(a=4.332)$ & B & $2 b$ & 0 & 0 & $1 / 2$ \\
\hline & & $c=5.949$ & $\mathrm{H}$ & $8 g$ & 0 & 0.2338 & 0.6179 \\
\hline & & $(c=5.869)$ & & & & $(0.2307)$ & $(0.6192)$ \\
\hline \multirow[t]{4}{*}{$\mathrm{KBH}_{4}$} & \multirow[t]{4}{*}{$P 4_{2} / n m c$ (No.137) } & $a=4.749$ & $\mathrm{~K}$ & $2 a$ & 0 & 0 & 0 \\
\hline & & $(a=4.684)$ & B & $2 b$ & 0 & 0 & $1 / 2$ \\
\hline & & $c=6.662$ & $\mathrm{H}$ & $8 g$ & 0 & 0.2131 & 0.6072 \\
\hline & & $(c=6.571)$ & & & & $(0.2100)$ & $(0.6060)$ \\
\hline
\end{tabular}
31 for $\mathrm{KBH}_{4}$ ). 
TABLE II. Structural parameters of $\mathrm{Zr}\left(\mathrm{BH}_{4}\right)_{4}$ and $\mathrm{Hf}\left(\mathrm{BH}_{4}\right)_{4}$.

\begin{tabular}{|c|c|c|c|c|c|c|c|}
\hline \multirow[b]{2}{*}{ Compound } & \multirow[b]{2}{*}{ Space group } & \multirow{2}{*}{$\begin{array}{l}\text { Lattice } \\
\text { parameters }(\AA)\end{array}$} & \multicolumn{5}{|c|}{ Atom parameters } \\
\hline & & & & Position & $x$ & $y$ & $z$ \\
\hline \multirow[t]{4}{*}{$\mathrm{Zr}\left(\mathrm{BH}_{4}\right)_{4}$} & $P \overline{4} 3 m($ No. 215$)$ & $a=5.795$ & $\mathrm{Zr}$ & $1 a$ & 0 & 0 & 0 \\
\hline & & & $\mathrm{B}$ & $4 e$ & 0.2301 & 0.2301 & 0.2301 \\
\hline & & & $\mathrm{H} 1$ & $4 e$ & 0.3493 & 0.3493 & 0.3493 \\
\hline & & & $\mathrm{H} 2$ & $12 i$ & 0.2604 & 0.2604 & 0.0173 \\
\hline \multirow[t]{4}{*}{$\mathrm{Hf}\left(\mathrm{BH}_{4}\right)_{4}$} & P23 (No.195) & $a=6.012$ & Hf & $1 a$ & 0 & 0 & 0 \\
\hline & & & $\mathrm{B}$ & $4 e$ & 0.2204 & 0.2204 & 0.2204 \\
\hline & & & $\mathrm{H} 1$ & $4 e$ & 0.3355 & 0.3355 & 0.3355 \\
\hline & & & $\mathrm{H} 2$ & $12 j$ & 0.2710 & 0.2256 & 0.0171 \\
\hline
\end{tabular}

calculated lattice constant and the measured one $\mathrm{s}^{30}(6.73 \AA)$ is very good. Though no soft-mode instabilities are found for the cubic phase, it has been reported that $\mathrm{KBH}_{4}$ also undergo a phase transition to the tetragonal structure with space group $\mathrm{P}_{2} / \mathrm{nmc}$ at $70-65 \mathrm{~K}^{31}$ The calculation for this phase gives small energy gain from the cubic phase, where the heat of formation is predicted as $\Delta H_{\text {boro }}=-231 \mathrm{~kJ} / \mathrm{mol} \mathrm{BH}_{4}$. The structural parameters of $\mathrm{NaBH}_{4}$ and $\mathrm{KBH}_{4}$ with $\mathrm{P}_{2} / n m c$ symmetry are given in Table I, which are in fairly good agreement with experimental data. ${ }^{29,31}$

Table II indicates the optimized structural parameters for $\mathrm{Zr}\left(\mathrm{BH}_{4}\right)_{4}$ and $\mathrm{Hf}\left(\mathrm{BH}_{4}\right)_{4}$. The structure of $\mathrm{Zr}\left(\mathrm{BH}_{4}\right)_{4}$ is cubic with space group $P \overline{4} 3 m .{ }^{32}$ Four $\mathrm{BH}_{4}$ complexes are tetrahedrally arranged around a $\mathrm{Zr}$ atom, where three of four hydrogen atoms in a $\mathrm{BH}_{4}$ complex form bridging bonds with $\mathrm{Zr}$. The optimized lattice constant is $a=5.795 \AA$ which agrees well with the experimental value ${ }^{32}$ of $5.86 \AA$. The heat of formation is predicted as $\Delta H_{\text {boro }}=-87 \mathrm{~kJ} / \mathrm{mol} \quad \mathrm{BH}_{4}$. $\mathrm{Hf}\left(\mathrm{BH}_{4}\right)_{4}$ with $P \overline{4} 3 m$ symmetry has a soft mode of $155 i \mathrm{~cm}^{-1}$. The eigenvectors correspond to nearly rigid rotations of $\mathrm{BH}_{4}$ complexes around Hf-B axes. Freezing this soft mode, the symmetry reduces to $P 23$ for which $\Delta H_{\text {boro }}=$
$-94 \mathrm{~kJ} / \mathrm{mol} \mathrm{BH}_{4}$. Similar reduction of the symmetry has been reported for a $\mathrm{Hf}\left(\mathrm{BH}_{4}\right)_{4}$ molecule. ${ }^{33}$

Although a synthesis of $\mathrm{Mg}\left(\mathrm{BH}_{4}\right)_{2}$ can be found in literature, ${ }^{34}$ in our knowledge, no structural information is available. Since the effective ionic radius of a $\left[\mathrm{BH}_{4}\right]^{-}$anion has been reported ${ }^{27}$ as $2.03 \AA$ which is close to the ionic radii of $\mathrm{Br}^{-}(1.96 \AA)$ and $\mathrm{I}^{-}(2.20 \AA)$, we refer the structures of $\mathrm{Mg}$ bromide and iodide to estimate the arrangement of cations and anions. The structure of $\mathrm{MgBr}_{2}$ and $\mathrm{MgI}_{2}$ is the $\mathrm{CdI}_{2}$ type which has a trigonal basic block composed of I-Cd-I layers; iodide anions form two triangle nets and cations occupy the octahedral sites between them. The $\mathrm{CdI}_{2}$ type structure contains four basic blocks. In order to determine the stable orientation of $\mathrm{BH}_{4}$ complexes, the structural optimization is performed for the unit cells containing one trigonal basic block, assuming several high symmetry orientations for $\mathrm{BH}_{4}$ complexes. The most stable structure found for this trigonal unit cell is given in Table III, where $\Delta H_{\text {boro }}=-99 \mathrm{~kJ} / \mathrm{mol} \mathrm{BH}_{4}$. Note that the cation-anion arrangement of $\mathrm{Mg}\left(\mathrm{AlH}_{4}\right)_{2}$ is the same as that of trigonal $\mathrm{Mg}\left(\mathrm{BH}_{4}\right)_{2}$, but the orientation of tetrahedral complex anions is different. ${ }^{35}$ When we assume the same orientation for complex anions as $\mathrm{Mg}\left(\mathrm{AlH}_{4}\right)_{2}, \Delta H_{\text {boro }}=-59 \mathrm{~kJ} / \mathrm{mol} \mathrm{BH}_{4}$. Al-

TABLE III. Structural parameters of $\mathrm{Mg}\left(\mathrm{BH}_{4}\right)_{2}$.

\begin{tabular}{|c|c|c|c|c|c|c|c|}
\hline \multirow[b]{2}{*}{ Phase } & \multirow[b]{2}{*}{ Space group } & \multirow{2}{*}{$\begin{array}{l}\text { Lattice } \\
\text { parameters }(\AA)\end{array}$} & \multicolumn{5}{|c|}{ Atom parameters } \\
\hline & & & & Position & $x$ & $y$ & $z$ \\
\hline \multirow[t]{4}{*}{ Trigonal } & \multirow[t]{4}{*}{$P \overline{3} m_{1}$ (No.164) } & $a=4.279$ & $\mathrm{Mg}$ & $1 a$ & 0 & 0 & 0 \\
\hline & & $c=5.761$ & $\mathrm{~B}$ & $2 d$ & $1 / 3$ & $2 / 3$ & 0.1877 \\
\hline & & & $\mathrm{H} 1$ & $2 d$ & $1 / 3$ & $2 / 3$ & 0.9752 \\
\hline & & & $\mathrm{H} 2$ & $6 i$ & 0.1792 & -0.1792 & 0.2688 \\
\hline \multirow[t]{6}{*}{ Monoclinic } & \multirow[t]{6}{*}{$P 2 / c$ (No.13) } & $a=6.777$ & $\mathrm{Mg}$ & $2 e$ & $1 / 4$ & 0.9997 & 0 \\
\hline & & $b=5.552$ & B & $4 g$ & 0.0583 & 0.8296 & 0.8051 \\
\hline & & $c=8.085$ & H1 & $4 g$ & 0.1040 & 0.8024 & 0.6524 \\
\hline & & $\beta=75.40^{\circ}$ & $\mathrm{H} 2$ & $4 g$ & 0.1840 & 0.7280 & 0.8705 \\
\hline & & & $\mathrm{H} 3$ & $4 g$ & 0.1064 & 0.2721 & 0.1289 \\
\hline & & & $\mathrm{H} 4$ & $4 g$ & 0.0495 & 0.0519 & 0.8348 \\
\hline
\end{tabular}




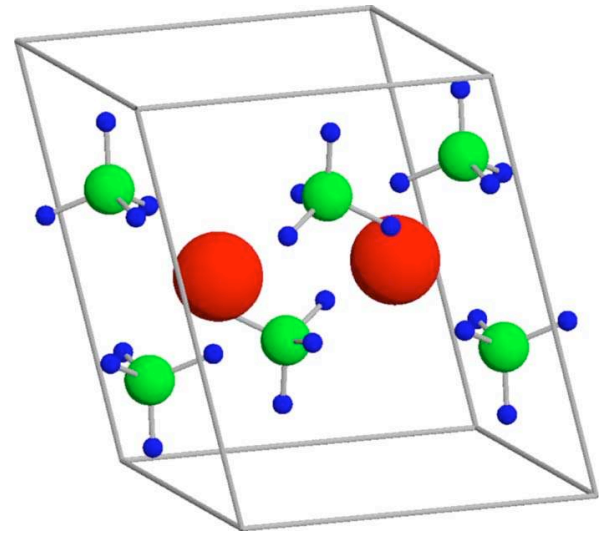

FIG. 1. (Color online) Crystal structure of monoclinic $\operatorname{Mg}\left(\mathrm{BH}_{4}\right)_{2}$. Red (large), green (middle), and blue (small) spheres represent $\mathrm{Mg}, \mathrm{B}$, and $\mathrm{H}$ atoms, respectively.

though we repeat the calculation for the $\mathrm{CdI}_{2}$-type structure using the obtained $\mathrm{BH}_{4}$ orientation, the heat of formation is hardly changed from that of the trigonal basic unit cell, indicating that the stacking of the basic blocks has only minor effects. Some of the trigonal basic unit cells have strong instability with the soft modes of $630 i-150 i \mathrm{~cm}^{-1}$, depending on the $\mathrm{BH}_{4}$ orientations assumed. We investigate these instability using the extended unit cells up to $2 \times 2$ in the lateral direction, from which the stable monoclinic structure is found with $\Delta H_{\text {boro }}=-104 \mathrm{~kJ} / \mathrm{mol} \mathrm{BH}_{4}$. Figure 1 shows the crystal structure of monoclinic $\mathrm{Mg}\left(\mathrm{BH}_{4}\right)_{2}$, the structural parameters of which are given in Table III. This heat of formation is the lowest value among the structures considered in this study. For examples, we also consider the structures of $\mathrm{Zn}$ bromide and iodide, since the ionic radius of $\mathrm{Zn}^{2+}$ is close to that of $\mathrm{Mg}^{2+}$. The structure of $\mathrm{ZnI}_{2}$ is the $\mathrm{CdCl}_{2}$ type, which has the same trigonal basic block as the $\mathrm{CdI}_{2}$-type structure but the stacking of the blocks is different. The predicted heat of formation for $\mathrm{CdCl}_{2}$-type $\mathrm{Mg}\left(\mathrm{BH}_{4}\right)_{2}$ is $-99 \mathrm{~kJ} / \mathrm{mol} \mathrm{BH}_{4}$ which is essentially the same as that of the trigonal basic unit cell. The $\mathrm{HgI}_{2}$ type is also the layer struc- ture; anions form two square nets and cations sit in the tetrahedral sites between them. Trying several $\mathrm{BH}_{4}$ orientations, we obtain $\Delta H_{\text {boro }}=-94 \mathrm{~kJ} / \mathrm{mol} \mathrm{BH}_{4}$ for $\mathrm{HgI}_{2}$-type $\operatorname{Mg}\left(\mathrm{BH}_{4}\right)_{2}$. Because our structural survey may be still limited, in a strict sense, the heat of formation predicted for the monoclinic phase, $\Delta H_{\text {boro }}=-104 \mathrm{~kJ} / \mathrm{mol} \mathrm{BH}_{4}$, gives only the upper bound for $\operatorname{Mg}\left(\mathrm{BH}_{4}\right)_{2}$. However, the heats of formation obtained for several prototypical structures are within the range of $10 \mathrm{~kJ} / \mathrm{mol} \mathrm{BH}{ }_{4}$ when the optimum $\mathrm{BH}_{4}$ orientations are chosen. This implies that $\Delta H_{\text {boro }}$ is not affected strongly by the cation-anion arrangements. We expect that, even if the more stable structure exists, its heat of formation is not so far away from our prediction.

The structure of $\mathrm{Zn}\left(\mathrm{BH}_{4}\right)_{2}$ is also undetermined and so we have performed the courses of the structural survey as done for $\operatorname{Mg}\left(\mathrm{BH}_{4}\right)_{2}$. The most stable structure is predicted to be triclinic with $\Delta H_{\text {boro }}=-18 \mathrm{~kJ} / \mathrm{mol} \mathrm{BH}_{4}$, whose structural parameters are given in Table IV. This structure is basically the same as that of monoclinic $\mathrm{Mg}\left(\mathrm{BH}_{4}\right)_{2}$. When the monoclinic symmetry is assumed for $\mathrm{Zn}\left(\mathrm{BH}_{4}\right)_{2}$, the weak instability with a soft mode of $20 i \mathrm{~cm}^{-1}$ appears. Trends that $\mathrm{Zn}\left(\mathrm{BH}_{4}\right)_{2}$ prefers lower symmetry than $\mathrm{Mg}\left(\mathrm{BH}_{4}\right)_{2}$ are also found for other prototypical structures. The optimized structures starting from the trigonal basic unit cell and the $\mathrm{HgI}_{2}$-type structure also become triclinic, for which the heats of formation are obtained as -7 and $-6 \mathrm{~kJ} / \mathrm{mol} \mathrm{BH}_{4}$, respectively.

For $\mathrm{Sc}\left(\mathrm{BH}_{4}\right)_{3}$, the cation-anion arrangement is assumed to be the $\mathrm{BiI}_{3}$-type (Pearson symbol, $h R 8$ ) with space group $R \overline{3}$. This is a simplified structure for $\mathrm{ScBr}_{3}$ which has the $h R 24$ structure with $R \overline{3}$ symmetry. The $\mathrm{BiI}_{3}$-type structure consists of the trigonal basic block similar to that of the $\mathrm{CdI}_{2}$ type; anions form two triangle nets and cations occupy $2 / 3$ of the octahedral sites between them. The structural optimization gives a puckered configuration for the cation layers and tilted orientations for $\mathrm{BH}_{4}$ complexes. The structural parameters of $\mathrm{BiI}_{3}$-type $\mathrm{Sc}\left(\mathrm{BH}_{4}\right)_{3}$ are listed in Table $\mathrm{V}$ and the corresponding atomic configuration for the trigonal basic block is shown in Fig. 2, where $\Delta H_{\text {boro }}=-105 \mathrm{~kJ} / \mathrm{mol} \mathrm{BH}_{4}$.

TABLE IV. Structural parameters of triclinic $\mathrm{Zn}\left(\mathrm{BH}_{4}\right)_{2}$.

\begin{tabular}{|c|c|c|c|c|c|c|}
\hline \multirow[b]{2}{*}{ Space group } & \multirow{2}{*}{$\begin{array}{l}\text { Lattice } \\
\text { parameters }(\AA)\end{array}$} & \multicolumn{5}{|c|}{ Atom parameters } \\
\hline & & & Position & $x$ & $y$ & $z$ \\
\hline \multirow[t]{11}{*}{$P \overline{1}($ No.2) } & $a=6.877$ & $\mathrm{Zn}$ & $2 i$ & 0.2498 & 0.0001 & 0.9998 \\
\hline & $b=5.440$ & B1 & $2 i$ & 0.0567 & 0.8903 & 0.7939 \\
\hline & $c=7.842$ & B2 & $2 i$ & 0.5497 & 0.1754 & 0.8166 \\
\hline & $\alpha=89.50^{\circ}$ & $\mathrm{H} 1$ & $2 i$ & 0.0997 & 0.8534 & 0.6382 \\
\hline & $\beta=76.15^{\circ}$ & $\mathrm{H} 2$ & $2 i$ & 0.5892 & 0.2640 & 0.6710 \\
\hline & $\gamma=89.98^{\circ}$ & $\mathrm{H} 3$ & $2 i$ & 0.1789 & 0.7718 & 0.8612 \\
\hline & & H4 & $2 i$ & 0.3316 & 0.7331 & 0.0999 \\
\hline & & H5 & $2 i$ & 0.1031 & 0.2267 & 0.1397 \\
\hline & & H6 & $2 i$ & 0.3863 & 0.2679 & 0.9011 \\
\hline & & $\mathrm{H} 7$ & $2 i$ & 0.0498 & 0.1135 & 0.8210 \\
\hline & & $\mathrm{H} 8$ & $2 i$ & 0.4481 & 0.0506 & 0.1928 \\
\hline
\end{tabular}


TABLE V. Structural parameters of $\mathrm{BiI}_{3}$-type $\mathrm{Sc}\left(\mathrm{BH}_{4}\right)_{3}$.

\begin{tabular}{|c|c|c|c|c|c|c|}
\hline \multirow[b]{2}{*}{ Space group } & \multirow{2}{*}{$\begin{array}{l}\text { Lattice } \\
\text { parameters }(\AA)\end{array}$} & \multicolumn{5}{|c|}{ Atom parameters } \\
\hline & & & Position & $x$ & $y$ & $z$ \\
\hline \multirow[t]{6}{*}{$R \overline{3}$ (No.148) } & $a=7.262$ & Sc & $6 c$ & 0 & 0 & 0.3210 \\
\hline & $c=18.194$ & B & $18 f$ & 0.3503 & 0.3123 & 0.4079 \\
\hline & & $\mathrm{H} 1$ & $18 f$ & 0.4002 & 0.3671 & 0.3423 \\
\hline & & $\mathrm{H} 2$ & $18 f$ & 0.3691 & 0.4611 & 0.4432 \\
\hline & & $\mathrm{H} 3$ & $18 f$ & 0.1636 & 0.1647 & 0.4130 \\
\hline & & $\mathrm{H} 4$ & $18 f$ & 0.4588 & 0.2370 & 0.4329 \\
\hline
\end{tabular}

In order to check the effect of the stacking of the trigonal basic blocks, the calculation is performed for the trigonal unit cell where the single block is repeated along the $c$ axis. The heat of formation obtained is slightly higher than that of the $\mathrm{BiI}_{3}$ type but the difference is less than $1 \mathrm{~kJ} / \mathrm{mol} \mathrm{BH}$. We confirm that the stacking of the blocks is less important.

Figure 3 depicts the densities of states for borohydrides described above. The electronic structures are nonmetallic with relatively large energy gaps of $2.9-6.8 \mathrm{eV}$. The occupied states mainly consist of $\mathrm{B}-s p^{3}$ hybrids and $\mathrm{H}-1 s$ orbitals. The contribution of metal atoms to the valence states are little except for the filled $3 d$ states found in $\mathrm{CuBH}_{4}$ and $\mathrm{Zn}\left(\mathrm{BH}_{4}\right)_{2}$. These figures support an ionic picture for the interaction between metal cations and $\left[\mathrm{BH}_{4}\right]^{-}$anions.

As mentioned in Refs. 12 and 17, the charge transfer from metal cations to $\left[\mathrm{BH}_{4}\right]^{-}$anions is expected to be a key feature for the stability of borohydrides. The ability of the charge transfer can be measured by the electronegativity, though the definition of the electronegativity is not unique and some formulations have been proposed. ${ }^{36-38}$ In this study, we use the Pauling scaling. ${ }^{36}$ Since the formulation of the Pauling electronegativity is based on the difference of binding energies between the elements, it will be suitable for the present purpose. In Fig. 4 , the heat of formation, $\Delta H_{\text {boro }}$, as a function of the Pauling electronegativity of the cation, $\chi_{P}$, is plotted, where the ZPE contributions to $\Delta H_{\text {boro }}$ are approximately taken into consideration by adding the correction of $33 \mathrm{~kJ} / \mathrm{mol} \mathrm{BH}_{4}$ estimated from the results for an isolated $\left[\mathrm{BH}_{4}\right]^{-}$anion and an $\mathrm{H}_{2}$ molecule. A good correlation between $\Delta H_{\text {boro }}$ and $\chi_{P}$ can be found. Assuming the linear relation, the least square fitting yields

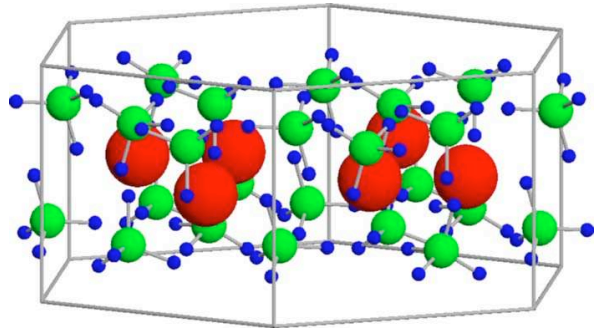

FIG. 2. (Color online) Atomic configuration for the trigonal basic block in $\mathrm{BiI}_{3}$-type $\mathrm{Sc}\left(\mathrm{BH}_{4}\right)_{3}$. Red (large), green (middle), and blue(small) spheres represent $\mathrm{Sc}, \mathrm{B}$, and $\mathrm{H}$ atoms, respectively. The $\mathrm{BiI}_{3}$-type $\mathrm{Sc}\left(\mathrm{BH}_{4}\right)_{3}$ consists of three blocks along the $c$ axis with $A B C$ stacking.

$$
\Delta H_{\text {boro }}=248.7 \chi_{P}-390.8,
$$

with an absolute mean error of $10.4 \mathrm{~kJ} / \mathrm{mol} \mathrm{BH}_{4}$. The Pauling electronegativity is a good indicator to estimate thermo-

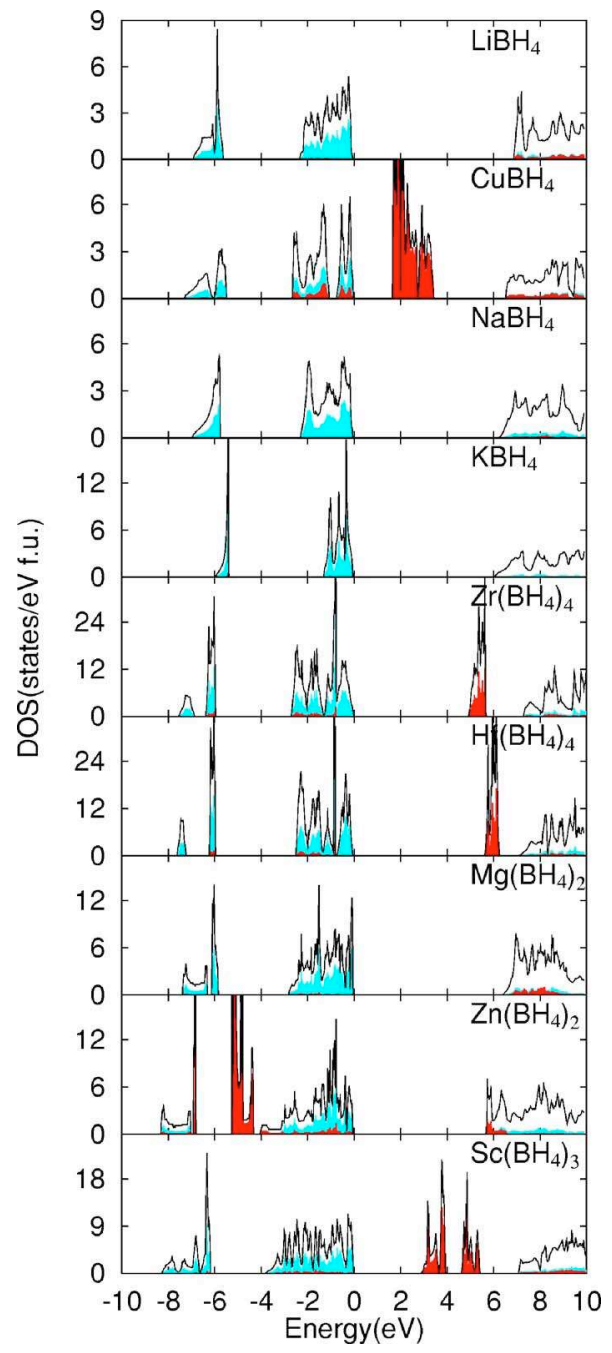

FIG. 3. (Color online) Total and partial densities of states (DOS) for borohydrides. The shaded-light (blue) parts indicate the partial DOS of boron and hydrogen atoms, and the shaded-dark (red) parts show the partial DOS of metal atoms. The origins of the energies are set to be the top of valence states except for $\mathrm{CuBH}_{4}$, where the energy is shifted by $+3.5 \mathrm{eV}$ for clear comparison. 


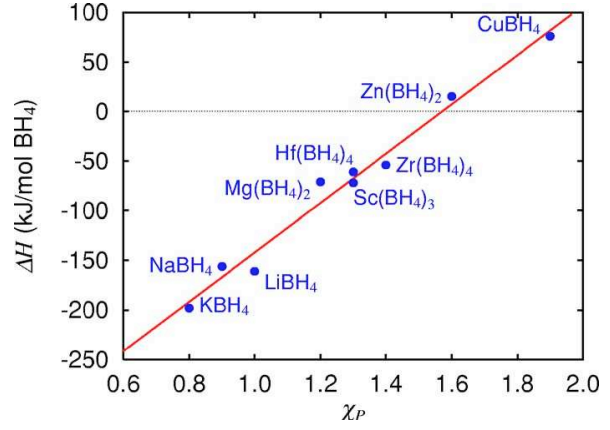

FIG. 4. (Color online) Relation between the heats of formation $\Delta H_{\text {boro }}$ and the Pauling electronegativities of cations, $\chi_{P}$. The straight line indicates the result of the least square fitting, $\Delta H_{\text {boro }}$ $=248.7 \chi_{P}-390.8$. The zero-point energy contributions to $\Delta H_{\text {boro }}$ are approximately taken into consideration (see the text).

dynamical stability of borohydrides. From this relation, it is expected that borohydrides with $\chi_{P} \geqslant 1.6$ are thermodynamically unstable.

We also investigate the Mulliken scaling, $\chi_{M} \cdot{ }^{37,39}$ The correlation between $\Delta H_{\text {boro }}$ and $\chi_{M}$ is fairly good except for $\mathrm{CuBH}_{4}$. The calculated data excluding $\mathrm{CuBH}_{4}$ can be fitted with an absolute mean error of $13.1 \mathrm{~kJ} / \mathrm{mol} \mathrm{BH}_{4}$. However, because the Mulliken electronegativities for $\mathrm{Cu}(4.48 \mathrm{eV})$ and $\mathrm{Zn}(4.45 \mathrm{eV})$ are almost the same, the difference of $\Delta H_{\text {boro }}$ between $\mathrm{CuBH}_{4}$ and $\mathrm{Zn}\left(\mathrm{BH}_{4}\right)_{2}$ can not be explained by $\chi_{M}$.

\section{B. Experimental support}

Based on the theoretical prediction in the preceding section, we have conducted the experiment to investigate the stabilities of borohydrides. Figure 5 shows the powder x-ray diffraction profiles of borohydrides. There are broad diffraction peaks at around 20 degree in all the profiles, originating from the diffraction of tape covering the samples to avoid (hydro-)oxidation by exposing air. The diffraction profile of $\mathrm{LiBH}_{4}$ is well identified as a single phase of orthorhombic structure at room temperature. Because the heat of formation for $\mathrm{CuBH}_{4}$ is a large positive value, $\mathrm{CuBH}_{4}$ could not be synthesized at room temperature. ${ }^{40} \mathrm{NaBH}_{4}$, and $\mathrm{KBH}_{4}$ crystallize in cubic symmetry with lattice constants of 6.163 and $6.727 \AA$, respectively, which are in good agreement with the theoretical prediction. $\mathrm{Mg}\left(\mathrm{BH}_{4}\right)_{2}, \mathrm{Zn}\left(\mathrm{BH}_{4}\right)_{2}, \mathrm{Sc}\left(\mathrm{BH}_{4}\right)_{3}$, $\mathrm{Zr}\left(\mathrm{BH}_{4}\right)_{4}$, and $\mathrm{Hf}\left(\mathrm{BH}_{4}\right)_{4}$ are mechanochemically synthesized according to Eq. (1). All the diffraction peaks after mechanical milling are identified as $\mathrm{LiCl}$, although the diffraction peaks of $\mathrm{LiCl}$ after the milling of $\mathrm{MgCl}_{2}$ and $2 \mathrm{LiBH}_{4}$ shift to lower angle, probably due to partial substitution of $\mathrm{Mg}$ for $\mathrm{Li}$ in $\mathrm{LiCl}$. It should be noted that there are no diffraction peaks of the starting materials of $M \mathrm{Cl}_{n}$ and $\mathrm{LiBH}_{4}$, showing the progression of reaction of Eq. (1). However, there are no diffraction peaks of $M\left(\mathrm{BH}_{4}\right)_{n}$ even though after annealing. This is most likely due to disordering of the crystal structure. We have reported that diffraction peaks became unclear and only small peaks were observed for rehydrogenated $\mathrm{LiBH}_{4}$, while the atomic vibrating modes of $\mathrm{BH}_{4}$ anions in $\mathrm{LiBH}_{4}$ were obviously detected. ${ }^{18,41}$ Therefore, we investigate the

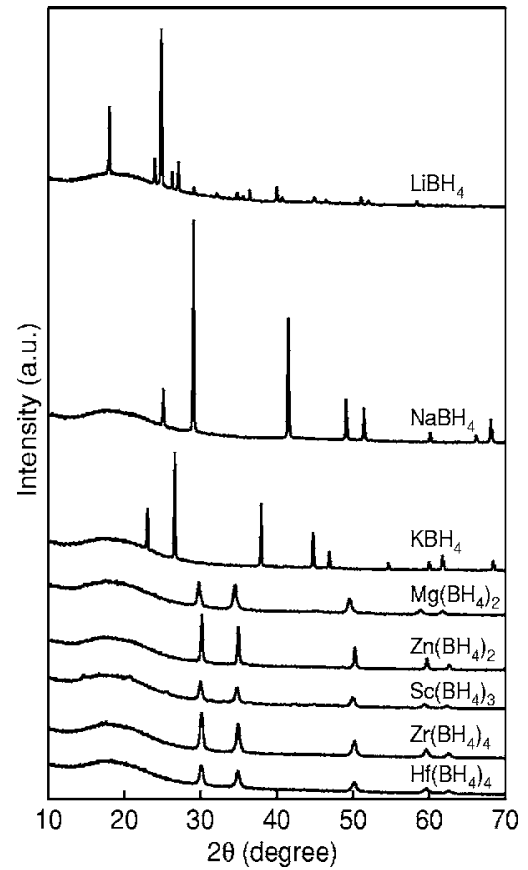

FIG. 5. Powder x-ray diffraction profiles of purchased $M \mathrm{BH}_{4}$ $(M=\mathrm{Li}, \mathrm{Na}$, and $\mathrm{K})$, and prepared $M\left(\mathrm{BH}_{4}\right)_{n}(M=\mathrm{Mg}, \mathrm{Zn}, \mathrm{Sc}, \mathrm{Zr}$, and Hf) by mechanical milling.

atomistic vibrations in order to confirm the existence of $M\left(\mathrm{BH}_{4}\right)_{n}$.

Figure 6 shows the Raman spectra of the purchased $\mathrm{MBH}_{4}(M=\mathrm{Li}, \mathrm{Na}$, and $\mathrm{K})$, and mechanochemically prepared $M\left(\mathrm{BH}_{4}\right)_{n}(M=\mathrm{Mg}, \mathrm{Zn}, \mathrm{Sc}, \mathrm{Zr}$, and Hf). Raman shift for $\mathrm{LiBH}_{4}, \mathrm{NaBH}_{4}$, and $\mathrm{KBH}_{4}$ are observed at around 1300 and $2300 \mathrm{~cm}^{-1}$, corresponding to the bending $\left(\nu_{2}\right.$, and also $\nu_{2}^{\prime}$ only for $\left.\mathrm{LiBH}_{4}\right)$ and stretching $\left(\nu_{1}\right)$ modes of $\mathrm{B}-\mathrm{H}$ in

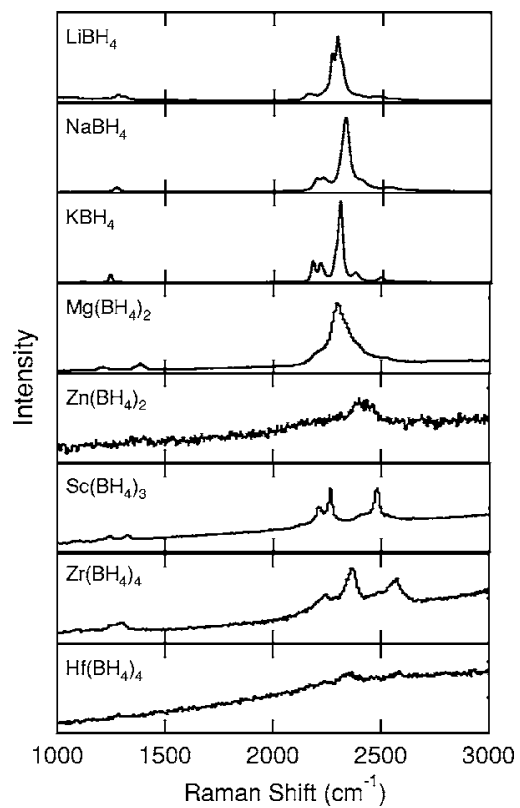

FIG. 6. Raman spectra of purchased $M \mathrm{BH}_{4}(M=\mathrm{Li}, \mathrm{Na}$, and K), and prepared $M\left(\mathrm{BH}_{4}\right)_{n}(M=\mathrm{Mg}, \mathrm{Zn}, \mathrm{Sc}, \mathrm{Zr}$, and $\mathrm{Hf})$ by mechanical milling. 


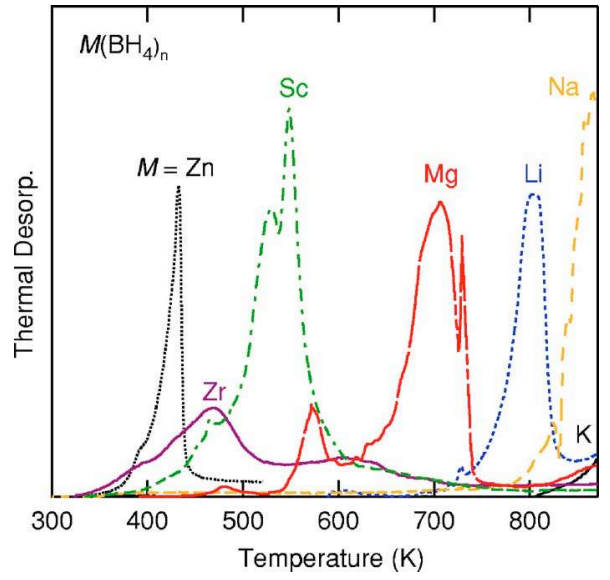

FIG. 7. (Color online) Thermal desorption profiles of $M\left(\mathrm{BH}_{4}\right)_{n}$.

$\mathrm{BH}_{4}$ anion. ${ }^{42}$ There are two bending and a stretching modes at around 1210, 1390, and $2300 \mathrm{~cm}^{-1}$ in the spectra of $\mathrm{Mg}\left(\mathrm{BH}_{4}\right)_{2}$, which are consistent with the IR spectra. ${ }^{43}$ The measurement of Raman spectroscopy for $\mathrm{Zn}\left(\mathrm{BH}_{4}\right)_{2}$ was very difficult, because the sample was charred by laser irradiation. A small peak at around $2450 \mathrm{~cm}^{-1}$ was barely observed when the irradiation time is as short as one second. There are three and four Raman shifts at around 1200-1400 and $2100-2600 \mathrm{~cm}^{-1}$ in the spectra of $\mathrm{Sc}\left(\mathrm{BH}_{4}\right)_{3}$, which are expected to be bending and stretching of B-H vibrating modes. At the same wave number of 1310 and $2250-2580 \mathrm{~cm}^{-1}$, bending and three stretching modes are observed for $\mathrm{Zr}\left(\mathrm{BH}_{4}\right)_{4}$ and $\mathrm{Hf}\left(\mathrm{BH}_{4}\right)_{4}$, which agrees roughly with the results in Refs. 44 and 33. The observed Raman modes are originated from the bending and stretching atomic vibrations in $\mathrm{BH}_{4}$ anion, and the modes of $M\left(\mathrm{BH}_{4}\right)_{n}(M=\mathrm{Mg}, \mathrm{Zn}, \mathrm{Sc}$, $\mathrm{Zr}$, and $\mathrm{Hf})$ are not the same as starting materials. We confirm $\mathrm{LiCl}$ and $M\left(\mathrm{BH}_{4}\right)_{n}$ in the sample after mechanical milling as products of Eq. (1) by X-ray diffraction measurement and Raman spectroscopy, respectively.

The hydrogen desorption reactions accompanying the phase decomposition were studied by thermal desorption analysis as shown in Fig. 7. Although, the prepared $M\left(\mathrm{BH}_{4}\right)_{n}$ for $M=\mathrm{Mg}, \mathrm{Zn}, \mathrm{Sc}, \mathrm{Zr}$, and $\mathrm{Hf}$ contain $\mathrm{LiCl}$, the thermal desorption profiles are originating from $M\left(\mathrm{BH}_{4}\right)_{n}$ only, because $\mathrm{LiCl}$ decomposes at higher temperature than its melting temperature of $878 \mathrm{~K} . \mathrm{MBH}_{4}$ for $M=\mathrm{Li}, \mathrm{Na}$, and $\mathrm{K}$ desorb hydrogen at higher temperature than $700 \mathrm{~K}$, in which alkali hydrides remain up to $873 \mathrm{~K} .{ }^{25}$ There are multi-step desorption peaks of $M\left(\mathrm{BH}_{4}\right)_{n}$ for $M=\mathrm{Mg}, \mathrm{Sc}$, and $\mathrm{Zr}$, which suggest that the hydrogen desorption reactions from borohydride to hydride, and then from hydride to element and/or boride as was reported in $\mathrm{Mg}\left(\mathrm{BH}_{4}\right)_{2} \cdot{ }^{43,45}$ There is a single desorption peak in $\mathrm{Zn}\left(\mathrm{BH}_{4}\right)_{2}$ because it decomposes directly to elemental $\mathrm{Zn}$ due to instabilities of $\mathrm{Zn}$ hydride and boride. The decomposition reaction of $\mathrm{Hf}\left(\mathrm{BH}_{4}\right)_{4}$ can not be studied because its boiling temperature of $391 \mathrm{~K}$, that is lower than the decomposition temperature. ${ }^{46}$

Here, the desorption temperature $T_{d}$ is defined as a temperature of the first peak. In Fig. 8, $T_{d}$ are plotted as a function of the Pauling electronegativity $\chi_{P}$. A good correlation

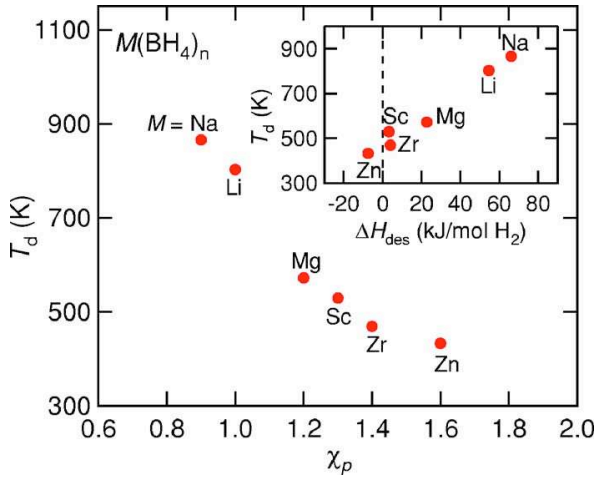

FIG. 8. (Color online) The desorption temperature $T_{d}$ as a function of the Pauling electronegativity $\chi_{P}$. Inset shows the correlation between $T_{d}$ and estimated $\Delta H_{\text {des }}$ for the desorption reaction of Eq. (4).

between the desorption temperature $T_{d}$ and the Pauling electronegativity $\chi_{P}$ is also observed experimentally, indicated that $T_{d}$ can be approximately estimated by considering $\chi_{P}$ as an indicator.

Since the desorption reactions are accompanied with the formation of hydrides and/or borides except for $\mathrm{Zn}\left(\mathrm{BH}_{4}\right)_{2}$ as mentioned above, the stability of decomposed products has to be taken into account. We assume that the borohydrides except for $\mathrm{Zn}\left(\mathrm{BH}_{4}\right)_{2}$ decompose to hydrides in the first desorption reaction as follow: ${ }^{47}$

$$
M\left(\mathrm{BH}_{4}\right)_{n} \rightarrow M \mathrm{H}_{m}+n \mathrm{~B}+\frac{4 n-m}{2} \mathrm{H}_{2} .
$$

The enthalpy change for this reaction, $\Delta H_{\text {des }}$, can be estimated using the predicted $\Delta H_{\text {boro }}$ for $M\left(\mathrm{BH}_{4}\right)_{n}$ and the experimental data for $M \mathrm{H}_{m}, \Delta H_{\text {hyd }}{ }^{48-50}$ The relation between estimated $\Delta H_{\text {des }}$ for the desorption reaction of Eq. (4) and the observed $T_{d}$ is shown in the inset of Fig. 8. There is also a good correlation between $\Delta H_{\text {des }}$ and $T_{d}$, indicating that the predicted stabilities of borohydrides are experimentally supported. Because the thermodynamical stabilities were well investigated for binary hydrides and borides, one can easily duduce $\Delta H_{\text {des }}$ using Eq. (3) for $M\left(\mathrm{BH}_{4}\right)_{n}$ and the reported data for binary hydrides and borides.

We detect by mass spectroscopy that the components of desorbed gas from $M\left(\mathrm{BH}_{4}\right)_{n}$ for $M=\mathrm{Li}, \mathrm{Na}, \mathrm{K}, \mathrm{Mg}$, Sc, and $\mathrm{Zr}\left(\chi_{P} \leqslant 1.4\right)$ are only hydrogen, while $\mathrm{Zn}\left(\mathrm{BH}_{4}\right)_{2}\left(\chi_{P}=1.6\right)$ desorbs also borane ${ }^{51,52}$ which might be related to the themodynamical instability predicted. On the other hand, $\mathrm{MBH}_{4}$ for $M=\mathrm{Li}, \mathrm{Na}$, and $\mathrm{K}\left(\chi_{P} \leqslant 1.0\right)$ are too stable, and their $T_{d}$ are high. The suitable $\chi_{P}$ in $M\left(\mathrm{BH}_{4}\right)_{n}$ for hydrogen storage is expected to be between them, approximately 1.2-1.5.

The observed $T_{d}$ are related to also kinetics, that may require higher temperatures than those predicted from the thermodynamical stabilities to promote desorption reactions. In order to precisely evaluate $\Delta H_{\text {des }}$ for the desorption reaction of $M\left(\mathrm{BH}_{4}\right)_{n}$ experimentally, the measurement of pressure composition isotherm is in progress.

\section{SUMMARY}

The thermodynamical stabilities of metal borohydrides, $M\left(\mathrm{BH}_{4}\right)_{n}(M=\mathrm{Li}, \mathrm{Na}, \mathrm{K}, \mathrm{Cu}, \mathrm{Mg}, \mathrm{Zn}, \mathrm{Sc}, \mathrm{Zr}$, and $\mathrm{Hf}$, 
$n=1-4)$ have been systematically investigated by firstprinciples calculations. In the cases of $M=\mathrm{Mg}, \mathrm{Zn}$, and $\mathrm{Sc}$, for which no structural information is available, the crystal structures are modeled by refering those of bromides and iodides, since the effective ionic radius of $\left[\mathrm{BH}_{4}\right]^{-}$is close to the ionic radii of $\mathrm{Br}^{-}$and $\mathrm{I}^{-}$. The electronic structures are found to be nonmetallic for all borohydrides considered in this study. The heats of formation normalized by the number of $\mathrm{BH}_{4}$ complexes, $\Delta H_{\text {boro }}$, show a good correlation with the Pauling electronegativities of cations, $\chi_{P}$, which is represented by the linear relation, $\Delta H_{\text {boro }}=248.7 \chi_{P}-390.8$ in the unit of $\mathrm{kJ} / \mathrm{mol} \mathrm{BH}_{4}$.

In order to investigate the thermal desorption temperatures experimentally, $M\left(\mathrm{BH}_{4}\right)_{n}(M=\mathrm{Mg}, \mathrm{Zn}, \mathrm{Sc}, \mathrm{Zr}$, and $\mathrm{Hf})$ were mechanochemically synthesized by milling of the mixture of $M \mathrm{Cl}_{n}$ and $\mathrm{LiBH}_{4}$. After mechanical milling, formations of $\mathrm{LiCl}$ and $M\left(\mathrm{BH}_{4}\right)_{n}$ are confirmed by x-ray diffraction measurement and Raman spectroscopy, respectively. The thermal desorption analyses are performed up to $873 \mathrm{~K}$, and the results indicate that $\mathrm{LiBH}_{4}, \mathrm{NaBH}_{4}$, and $\mathrm{KBH}_{4}$ desorb hydrogen to hydride phases. $\mathrm{Mg}\left(\mathrm{BH}_{4}\right)_{2}, \mathrm{Sc}\left(\mathrm{BH}_{4}\right)_{3}$, and $\mathrm{Zr}\left(\mathrm{BH}_{4}\right)_{4}$ show multistep desorption reactions through the intermediate phases of hydrides and/or borides. On the other hand, $\mathrm{Zn}\left(\mathrm{BH}_{4}\right)_{2}$ desorbs hydrogen to elemental $\mathrm{Zn}$ due to instabilities of $\mathrm{Zn}$ hydride and boride, although desorbed gas contains also borane. A good correlation between the desorption temperature $T_{d}$ and $\chi_{P}$ is observed experimentally and so $\chi_{P}$ is an indicator to approximately estimate the stability of $M\left(\mathrm{BH}_{4}\right)_{n}$. The estimated $\Delta H_{\text {des }}$ for the desorption reaction show a good correlation with $T_{d}$. Therefore, $\Delta H_{\text {des }}$ as an indicator for exploring useful hydrogen storage materials with appropriate stability, can be estimated using $\Delta H_{\text {boro }}$ for $M\left(\mathrm{BH}_{4}\right)_{n}$ predicted in this study and $\Delta H_{\text {hyd/boride }}$ reported extensively.

\section{ACKNOWLEDGMENTS}

The authors would like to thank T. Noritake, M. Aoki, and S. Hyodo for valuable discussions, and N. Warifune for technical support. This study was partially supported by the New Energy and Industrial Technology Development Organization (NEDO), International Joint Research under the "Development for Safe Utilization and Infrastructure of hydrogen" Project (2005-2006), and by the Ministry of Education, Science, Sports and Culture, Grant-in-Aid for Encouragement of Young Scientists (B), Grant No. 17760555 and for Scientific Research (A), Grant No. 18206073.

\section{APPENDIX}

In this appendix, we calculate the ZPE contribution to the heat of formation for tetragonal $\mathrm{NaBH}_{4}$ with $\mathrm{P}_{2} / n m c$ symmetry in order to examine approximate treatment for the ZPE correction described in Sec. III A. The zero-point energies are obtained within the harmonic approximation and the phonon eigenmodes are calculated by the force-constant method ${ }^{53}$ For bcc-Na, the zero-point energy is predicted as $16 \mathrm{meV} / \mathrm{atom}$, where the supercell containing 64 atoms with the theoretical lattice constant of $a=4.184 \AA$ are used. The
TABLE VI. Dielectric properties of tetragonal $\mathrm{NaBH}_{4}$. Macroscopic high-frequency dielectric permittivity tensors $\varepsilon_{\infty}$ and Born effective charge tensor $Z^{*}$. The $y y$ element is the same as $x x$, and $\left|Z_{x y}^{*}\right|=\left|Z_{y x}^{*}\right|,\left|Z_{y z}^{*}\right|=\left|Z_{x z}^{*}\right|$, and $\left|Z_{z x}^{*}\right|=\left|Z_{z y}^{*}\right|$ for $Z_{\mathrm{H}}^{*}$.

\begin{tabular}{lccccc}
\hline \hline & $x x$ & $z z$ & $x y$ & $y z$ & $z x$ \\
\hline$\varepsilon_{\infty}$ & 2.56 & 2.50 & 0 & 0 & 0 \\
$Z_{\mathrm{Na}}^{*}$ & 1.14 & 1.16 & 0 & 0 & 0 \\
$Z_{\mathrm{B}}^{*}$ & 0.20 & 0.17 & 0 & 0 & 0 \\
$Z_{\mathrm{H}}^{*}$ & -0.34 & -0.33 & \pm 0.15 & \pm 0.16 & \pm 0.14 \\
\hline \hline
\end{tabular}

zero-point energies are 126 and $135 \mathrm{meV} / \mathrm{atom}$ for $\alpha$-B and $\mathrm{H}_{2}$, respectively. ${ }^{12}$

The zero-point energy for $\mathrm{NaBH}_{4}$ is estimated from only the $\Gamma$-phonon eigenmodes as done for $\mathrm{LiBH}_{4}{ }^{12}$ Since the tetragonal unit cell contains two formula units, there are 33 optical $\Gamma$-phonon modes. The irreducible representation of them is $2 A_{1 g}+A_{2 g}+B_{1 g}+4 B_{2 g}+5 E_{g}+A_{1 u}+3 A_{2 u}+2 B_{1 u}+B_{2 u}$ $+4 E_{u}$; gerade modes except for $A_{2 g}$ are Raman active, $A_{2 u}$ and $E_{u}$ modes are infrared active, and others are inactive. The infrared active modes are divided into the transverse optical (TO) modes and the longitudinal optical (LO) modes. Knowledge of the dielectric properties is required to treat this splitting. Table VI summarizes the dielectric properties, which are obtained using the linear response calculation. ${ }^{54,55}$ These values are quite similar to those of $\mathrm{LiBH}_{4}$. The $\Gamma$-phonon frequencies of tetragonal $\mathrm{NaBH}_{4}$ are listed in Table VII, from which the zero-point energy is obtained as $172 \mathrm{meV} / \mathrm{atom}$. The eigenmodes around $1100-1300$ and $2300-2400 \mathrm{~cm}^{-1}$ originate from the internal B-H bending and stretching vibrations of $\mathrm{BH}_{4}$ complexes. These frequencies are in good agreement with the Raman spectroscopy measurements given in Sec. III B.

Using the zero-point energies obtained in this Appendix, the ZPE correction to $\Delta H_{\text {boro }}$ is predicted to be $34 \mathrm{~kJ} / \mathrm{mol}$ $\mathrm{BH}_{4}$ for tetragonal $\mathrm{NaBH}_{4}$. This is in good agreement with the estimated value of $33 \mathrm{~kJ} / \mathrm{mol} \mathrm{BH}_{4}$. This supports approximate treatment for the ZPE correction adopted in Sec. III A.

TABLE VII. Optical $\Gamma$-phonon frequencies $\left(\mathrm{cm}^{-1}\right)$ of tetragonal $\mathrm{NaBH}_{4}$.

\begin{tabular}{lccccc}
\hline \hline Modes & \multicolumn{5}{c}{ Frequencies } \\
\hline$A_{1 g}$ & 1241 & 2323 & & & \\
$A_{2 g}$ & 353 & & & & \\
$B_{1 g}$ & 1231 & & & & \\
$B_{2 g}$ & 132 & 238 & 1104 & 2380 & \\
$E_{g}$ & 95 & 140 & 333 & 1091 & 2345 \\
$A_{1 u}$ & 1220 & & & & \\
$A_{2 u}(\mathrm{TO})$ & 177 & 1097 & 2343 & & \\
$A_{2 u}(\mathrm{LO})$ & 283 & 1106 & 2380 & & \\
$B_{1 u}$ & 1240 & 2317 & & & \\
$B_{2 u}$ & 170 & & & & \\
$E_{u}(\mathrm{TO})$ & 137 & 231 & 1079 & 2316 & \\
$E_{u}(\mathrm{LO})$ & 227 & 258 & 1089 & 2350 & \\
\hline \hline
\end{tabular}


*Electronic address: miwa@cmp.tytlabs.co.jp

†Electronic address: orimo@imr.tohoku.ac.jp

${ }^{1}$ B. Bogdanović and M. Schwickardi, J. Alloys Compd. 253, 1 (1997).

${ }^{2}$ R. A. Zidan, S. Takara, A. G. Hee, and C. M. Jensen, J. Alloys Compd. 285, 119 (1999).

${ }^{3}$ L. Zaluski, A. Zaluska, and J. O. Ström-Olsen, J. Alloys Compd. 290, 71 (1999).

${ }^{4}$ K. J. Gross, S. Guthrie, S. Takara, and G. Thomas, J. Alloys Compd. 297, 270 (2000).

${ }^{5}$ B. Bogdanović, R. A. Brand, A. Marjanvić, M. Schwickardi, and J. Tölle, J. Alloys Compd. 302, 36 (2000).

${ }^{6}$ C. M. Jensen and K. J. Gross, Appl. Phys. A: Mater. Sci. Process. 71, 213 (2001).

${ }^{7}$ D. Sun, T. Kiyobayashi, H. Takeshita, N. Kuriyama, and C. M. Jensen, J. Alloys Compd. 337, L8 (2002).

${ }^{8}$ G. P. Meisner, G. G. Tibbetts, F. E. Pinkerton, C. H. Olk, and M. P. Balogh, J. Alloys Compd. 337, 254 (2002).

${ }^{9}$ G. Sandrock, K. Gross, and G. Thomas, J. Alloys Compd. 339, 299 (2002)

${ }^{10}$ H. Morioka, K. Kakizaki, S. C. Chung, and A. Yamada, J. Alloys Compd. 353, 310 (2003).

${ }^{11}$ A. Züttel, P. Wenger, S. Rentsch, P. Sudan, Ph. Mauron, and Ch. Emmenegger, J. Power Sources 118, 1 (2003).

${ }^{12}$ K. Miwa, N. Ohba, S. Towata, Y. Nakamori, and S. Orimo, Phys. Rev. B 69, 245120 (2004).

${ }^{13}$ M. E. Arroyo and G. Ceder, J. Alloys Compd. 364, 6 (2004).

${ }^{14}$ Z. Lodziana and T. Vegge, Phys. Rev. Lett. 93, 145501 (2004).

${ }^{15}$ P. Vajeeston, P. Ravindran, A. Kjekshus, and H. Fjellvåg, J. Alloys Compd. 387, 97 (2005).

${ }^{16}$ N. Ohba, K. Miwa, M. Aoki, T. Noritake, S. Towata, Y. Nakamori, S. Orimo, and A. Züttel, cond-mat/0606228 (unpublished).

${ }^{17}$ K. Miwa, N. Ohba, S. Towata, Y. Nakamori, and S. Orimo, J. Alloys Compd. 404-406, 140 (2005).

${ }^{18}$ S. Orimo, Y. Nakamori, G. Kitahara, K. Miwa, N. Ohba, S. Towata, and A. Züttel, J. Alloys Compd. 404-406, 427 (2005).

${ }^{19}$ For $\mathrm{LiBH}_{4}$, the latent heats for structural change at $381 \mathrm{~K}$ and fusion at $540 \mathrm{~K}$ has been reported as 4.2 and $7.6 \mathrm{~kJ} / \mathrm{mol}$, respectively; M. B. Smith and G. E. Bass Jr., J. Chem. Eng. Data 8, 342 (1963).

${ }^{20}$ D. Vanderbilt, Phys. Rev. B 41, R7892 (1990); K. Laasonen, A. Pasquarello, R. Car, C. Lee, and D. Vanderbilt, ibid. 47, 10142 (1993).

${ }^{21}$ P. Hohenberg and W. Kohn, Phys. Rev. 136, B864 (1964); W. Kohn and L. J. Sham, Phys. Rev. 140, A1133 (1965).

${ }^{22}$ J. P. Perdew, K. Burke, and M. Ernzerhof, Phys. Rev. Lett. 77, 3865 (1996); 78, 1396 (1997).

${ }^{23}$ V. E. Wiberg and W. Henle, Z. Naturforsch. B 7b, 579 (1952).

${ }^{24}$ V. V. Volkov, K. G. Myakishev, and S. I. Yugov, J. Appl. Chem. USSR 48, 2184 (1975).

${ }^{25}$ S. Orimo, Y. Nakamori, and A. Züttel, Mater. Sci. Eng., B 108, $51(2003)$

${ }^{26}$ Y. Nakamori, A. Ninomiya, G. Kitahara, M. Aoki, T. Noritake, K. Miwa, Y. Kojima, and S. Orimo, J. Power Sources 155, 447 (2006).

${ }^{27}$ C. W. F. T. Pistorius, Z. Phys. Chem., Neue Folge 88, 253 (1974).

${ }^{28}$ A. M. Soldate, J. Am. Chem. Soc. 69, 987 (1947).
${ }^{29}$ P. Fischer and A. Züttel, Mater. Sci. Forum 443-444, 287 (2004).

${ }^{30}$ S. C. Abrahams and K. Kalnajs, J. Chem. Phys. 22, 434 (1954).

${ }^{31}$ G. Renaudin, S. Gomes, H. Hagemann, L. Keller, and K. Yvon, J. Alloys Compd. 375, 98 (2004).

${ }^{32}$ P. H. Bird and M. R. Churchill, Chem. Commun. (London) 1967, 403 (1967).

${ }^{33}$ J. O. Jensen, Spectrochim. Acta, Part A 59, 379 (1993).

${ }^{34}$ E. A. Sullivan and R. C. Wade, Gravity Concentration to Hydrogen Energy, Kirk-Othmer Encyclopedia of Chem. Tech. Vol. 12, 3rd ed. (Wiley-Interscience, New York, 1980), p. 772.

${ }^{35}$ M. Fichtner, J. Engel, O. Fuhr, A. Glöss, O. Rubner, and R. Ahlrichs, Inorg. Chem. 42, 7060 (2003).

${ }^{36}$ L. Pauling, The Nature of the Chemical Bonds, 3rd ed. (Cornell University Press, New York, 1960).

${ }^{37}$ R. S. Mulliken, Chem. Phys. 2, 783 (1934).

${ }^{38}$ A. L. Allred and E. G. Rochow, J. Inorg. Nucl. Chem. 5, 264 (1958).

${ }^{39}$ R. G. Parr and R. G. Pearson, J. Am. Chem. Soc. 105, 7512 (1983).

${ }^{40}$ T. J. Klingen, Inorg. Chem. 3, 1058 (1964).

${ }^{41}$ Our preliminary measurement of pressure-composition isotherm for $\mathrm{LiBH}_{4}$ indicated that $\Delta H$ was not affected by disordering of the crystal structure. The thermal desorption profile with disorderirng of the crystal structure was similar to that without disordering as shown in Ref. 18. The observed disordering of the crystal structure made a very small impact on $T_{d}$.

${ }^{42}$ J.-Ph. Soulié, G. Renaudin, R. Eerný, and K. Yvon, J. Alloys Compd. 346, 200 (2002).

${ }^{43}$ V. N. Konoplev and V. M. Bakulina, Izv. Akad. Nauk. SSR, Ser. Khi. 1, 159 (1971).

${ }^{44}$ N. Davies, M. G. H. Wallbridge, B. E. Smith, and B. D. James, J. Chem. Soc. Dalton Trans. 1977, 710.

${ }^{45}$ T. Matsunaga, F. Buchter, K. Miwa, S. Towata, S. Orimo, and A. Züttel (unpublished).

${ }^{46}$ H. R. Hoekstra and J. J. Katz, J. Am. Chem. Soc. 71, 2488 (1949).

${ }^{47}$ The decomposed products for $M=\mathrm{Sc}$ and $\mathrm{Zr}$ could not be clarified, because only $\mathrm{LiCl}$ was observed experimentally in the $\mathrm{x}$-ray diffraction profile after desorption reactions.

${ }^{48}$ The used $\Delta H_{\text {hyd }}$ of $M H_{m}$ are $-118,-114,-158,-74,-200$, and $-188 \mathrm{~kJ} / \mathrm{mol} \mathrm{H}_{2}$ for $\mathrm{KH}, \mathrm{NaH}, \mathrm{LiH}, \mathrm{MgH}_{2}, \mathrm{ScH}_{2}$, and $\mathrm{ZrH}_{2}$, respectively. Since $\mathrm{Zn}$ hydride is unstable, $\Delta H_{\text {des }}$ of $\mathrm{Zn}\left(\mathrm{BH}_{4}\right)_{2}$ was deduced from Eq. (2) assuming that only hydrogen is desorbed.

${ }^{49} \mathrm{http}: / /$ hydpark.ca.sandia.gov/MaterialsFrame2.html

${ }^{50}$ Phase Diagrams of Binary Hydrogen Alloys, edited by F. D. Manchester (ASM International, 2000).

${ }^{51}$ The components of desorbed gas and mechanochemically synthesis for $\mathrm{Zn}\left(\mathrm{BH}_{4}\right)_{2}$ have been also reported by Jeon and Cho recently; E. Jeon and Y. W. Cho, J. Alloys Compd. (to be published).

${ }^{52}$ Y. Nakamori, H.-W. Li, K. Miwa, S. Towata, and S. Orimo, Mater. Trans. (to be published).

${ }^{53}$ K. Kunc and R. M. Martin, Phys. Rev. Lett. 48, 406 (1982).

${ }^{54}$ X. Gonze and C. Lee, Phys. Rev. B 55, 10355 (1997).

${ }^{55}$ N. Ohba, K. Miwa, N. Nagasako, and A. Fukumoto, Phys. Rev. B 63, 115207 (2001). 